\title{
Mapping Miles and Huberman's Within-Case and Cross-Case Analysis Methods onto the Literature Review Process
}

\author{
Anthony J. Onwuegbuzie (Corresponding author) \\ Department of Educational Leadership and Counseling, Box 2119 \\ Sam Houston State University, Huntsville, Texas 77341-2119, USA \\ Tel: 1-936-294-4509Ｅ-mail: tonyonwuegbuzie@aol.com \\ Rebecca K. Weinbaum \\ Department of Counseling and Special Populations \\ Lamar University, 223 Education Building, Beaumont, Texas 77710, USA \\ E-mail: rebecca.frels@gmail.com
}

Received: March 25, 2016 Accepted: April 22, 2016 Published: May 14, 2016

doi:10.5296/jei.v2i1.9217ＵRL: http://dx.doi.org/10.5296/jei.v2i1.9217

\begin{abstract}
Recently, several authors have attempted to make the literature review process more transparent by providing a step-by-step guide to conducting literature reviews. However, although these works are very informative, none of them delineate how to display information extracted from literature reviews in a reader-friendly and visually appealing manner. Thus, the purpose of this article was to provide a framework for visually displaying information extracted for literature reviews via Miles and Huberman's (1994) within- and cross-case displays. As part of our demonstration of the utility of visual displays, we use an actual body of published works that were subjected to some of these displays. Finally, we illustrate how to use a qualitative data analysis software program to facilitate these visual displays.
\end{abstract}

Keywords: Literature review, Synthesis, Data analysis, Data displays, Cross-case analysis, Within-case analysis 


\section{Introduction}

The literature review is the most important step in the research process in all empirical studies-whether the study represents a quantitative, qualitative, or mixed research study-because without it, the researcher(s) would not have an up-to-date awareness about what is known regarding the phenomenon of interest and, subsequently, where the gaps in the knowledge are. Onwuegbuzie, Collins, Leech, Dellinger, and Jiao (2010) identified reasons for conducting a review of the literature. Figure 1 presents our typology of reasons for a literature review that comprises some of the most common reasons that researchers use to conduct literature reviews. We have categorized these reasons into three major areas: topic-driven focused, method-driven focused, and connection-driven focused. 


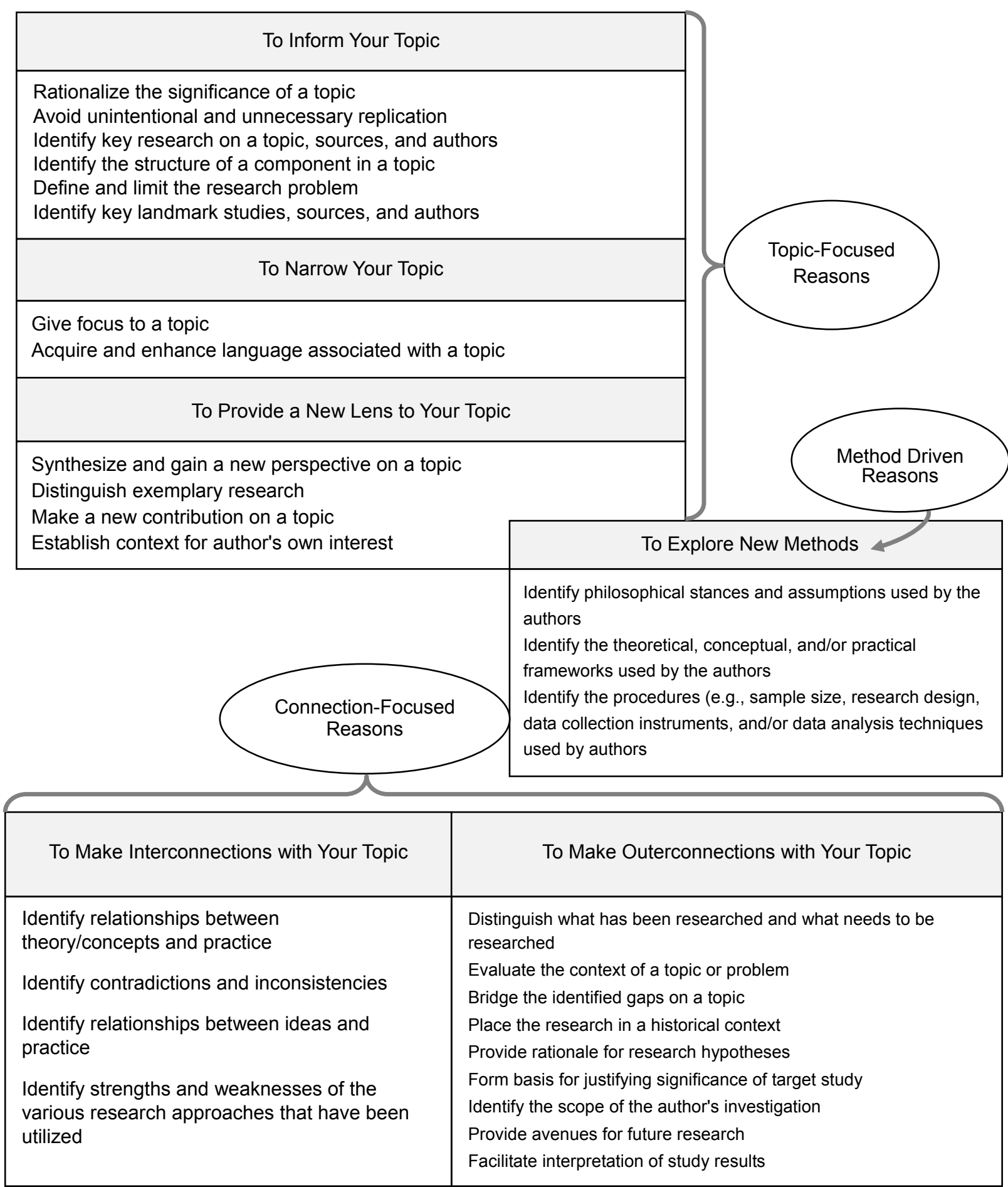

Figure 1. Common reasons for conducting a literature review

Despite its importance, there are less published works focusing on the literature review than any other component of the research process. Also disturbing is the fact that virtually every research methodology textbook author devotes at most one chapter to discussing the literature review process; yet, these same textbook authors devote several chapters to other phases of the research process such as the research design phase and data analysis phase (Onwuegbuzie 
\& Leech, 2005). Further, as few as $2 \%$ of graduate school programs provide students with the option to take formal literature review courses (Onwuegbuzie, Leech, \& Collins, 2011). This lack of published works on the literature review alongside the lack of formal and systematic instruction on conducting literature reviews explain why numerous beginning researchers (Boote \& Beile, 2005) and experienced researchers (Onwuegbuzie \& Daniel, 2005) alike have difficulties conducting and writing quality literature reviews, with as many as $40 \%$ of manuscripts that are initially submitted to journals containing inadequate literature reviews, and with these manuscripts that contain poorly written literature reviews being more than six times more likely than are their counterparts to be rejected for publication (Onwuegbuzie \& Daniel, 2005).

Recently, several authors have attempted to make the literature review process more transparent by providing a step-by-step guide to conducting literature reviews (i.e., Combs, Bustamante, \& Onwuegbuzie, 2010; Dellinger \& Leech, 2007; Fink, 2009; Garrard, 2009; Hart, 2005; Leech, Dellinger, Brannagan, \& Tanaka, 2010; Machi \& McEvoy, 2009; Onwuegbuzie et al., 2010; Onwuegbuzie \& Frels, 2012, 2014; Onwuegbuzie, Leech, \& Collins, 2012; Ridley, 2008). However, although these works are very informative, virtually none of these textbooks provide explicit instructions as how to analyze and to interpret selected literature using existing data analytic techniques. Moreover, although these works delineate some useful strategies for analyzing and interpreting selected literature, none of them provide sufficient detail as to how to display this information in a reader-friendly and visually appealing manner. Thus, the purpose of this article was to provide a framework for visually displaying information extracted from literature reviews.

\section{Theoretical Framework}

\subsection{Theoretical Framework 1: Levels of Visual Display}

Tufte (2001) identified the following five broad levels of visual display: (a) text (i.e., level 1), (b) tables (i.e., level 2), (c) text-tables (i.e., level 3), (d) supertables (i.e. level 4), and (e) graphics (i.e., level 5). Specifically, text (i.e., narrative) represents the conventional sentence. Tables most commonly are used to display numerical values. Contrastingly, text-tables summarize data by type and source of information (e.g., demographic information, data source and time, group membership) by "arranging the type to facilitate comparison" (Tufte, 2001, p. 178). Supertables, "a type of elaborate table," can be used to "attract readers through its organized, sequential detail, and reference-like quality" (Tufte, 2001, p. 179). Finally, graphics make "complexity accessible: combining words, numbers, and pictures;" giving "access to the richness of data makes graphics more attractive to the viewer" (Tufte, 2001, p. 180). Whereas text - the lowest level of visual display — solely characterizes the vast majority of literature review reports, graphics - the highest level of visual display - are extremely underutilized in literature review reports (Onwuegbuzie \& Frels, 2016). Yet, this form of visual display has much intuitive appeal because it involves the combining of qualitative and quantitative information within the same representation-or what Onwuegbuzie and Dickinson (2008) refer to as "crossover visual extensions" or "crossover visual displays" (p. 205) — which facilitate what Onwuegbuzie and Combs (2010) refer to as "crossover mixed 
analyses" (p. 423), which involves using one or more analysis types associated with one tradition (e.g., qualitative analysis) to analyze data associated with a different tradition (e.g., quantitative data). And supporting our recommendation to use graphics to represent quantitative and qualitative information extracted from literature reviews is the fact that, optimally, the literature review process involves the collection, analysis, and interpretation of both qualitative and quantitative data (i.e., information) (Onwuegbuzie et al., 2010). For example, at the very least, the following elements of every empirical source that informs literature reviews contain quantitative information:

$>$ sample size(s) pertaining to every quantitative, qualitative, and mixed research study selected for the literature review analysis and synthesis;

$>$ findings (e.g., descriptive statistics, score reliability, p-values, effect sizes, confidence interval, meta-analysis information) pertaining to each quantitative study presented in the literature review section of the source;

$>$ findings presented in the results section of each quantitative study selected for the literature review.

Also, the following elements of the research study contain qualitative information:

$>$ information about the sample characteristics pertaining to every quantitative, qualitative, and mixed research study selected for the literature review analysis and synthesis;

$>$ findings (e.g., themes, meta-themes, metaphors, quotations, narrative) pertaining to each qualitative research study presented in the literature review section of the source;

$>$ findings presented in the results section of each qualitative research study selected for the literature review;

$>$ information from the discussion/conclusion section of every quantitative, qualitative, and mixed research study selected for the literature review.

Indeed, because of the array of quantitative and qualitative data that are potentially inherent in each work, every literature review (potentially) lends itself simultaneously to the analysis of quantitative and qualitative information. Consequently, every literature review optimally involves the use of mixed research techniques (Onwuegbuzie et al., 2010).

Interestingly, Tufte (2006) identified six fundamental principles of analytical design: (a) comparison; (b) multivariate analysis; (c) causality, mechanism, structure, and explanation; (d) integration of evidence; (e) documentation; and (f) content. These principles are not ordered by levels of complexity; rather, each principle represents a discrete element. As surmised by Tufte (2006), "Visual displays, if they are to assist thinking, should show comparisons" (p. 127 ) and "the reason we examine evidence is to understand causality, process, and systemic structure" (Tufte, 2006, p. 128). And by incorporating quantitative and qualitative data within the same graphical depiction, literature reviewers can undertake a richer and thicker (Geertz, 1973) analysis of information extracted via the literature review process. In turn, as posited by Onwuegbuzie and Dickinson (2008), 
Literature reviewers can analyze the relationship among variables, based on the resultant visual patterns of their observed values. These multiple pieces of evidence provide documentation of our dataset, and a visual summary of narrative content. Graphics give data a "voice"; enabling our data to speak to us in a nonverbal way (Dickinson, Hines, \& Onwuegbuzie, 2006). (p. 206)

\subsection{Theoretical Framework 2: Within-Case and Cross-Case Displays}

\subsubsection{Within-Case Displays}

Miles and Huberman (1994) constructed an array of visual displays (i.e., $n=19$ ) for one case at a time (i.e., within-case displays). According to these authors, within-case displays comprise the four following types: partially ordered displays, time-ordered displays, role-ordered displays, and conceptually ordered displays. Specifically, partially ordered displays are visual representations that reveal and display what is occurring within a local context or setting by imposing minimal conceptual structure on the data, which range from Level 1 display (e.g., poems) to Level 5 display (e.g., context charts; cf. Table 1). Time-ordered displays are visual representations wherein data are ordered by time and sequence, retaining the historical chronological order of events and facilitating an analysis of when the events occurred and their antecedents, which range from Level 3 (e.g., critical incident chart; cf. Table 1) to Level 5 (e.g., growth gradient; cf. Table 1). Role-ordered displays order information according to the participant's roles in a formal or informal setting, all of which operate at Level 3 (e.g., role-by-time matrix; cf. Table 1). Finally, conceptually ordered displays order the display by concepts or variables, which range from Level 3 (e.g., conceptually clustered matrix; cf. Table 1) to Level 5 (e.g., causal network; cf. Table 1).

Table 1. Miles and Huberman's (1994) within-case displays

\begin{tabular}{|c|c|}
\hline Type of Display & Description \\
\hline \multicolumn{2}{|l|}{ Partially Ordered } \\
\hline Poem & Composition in verse \\
\hline Context chart & $\begin{array}{l}\text { Networks that map in graphic form the interrelationships among } \\
\text { groups and roles that underlie the context of individual behavior }\end{array}$ \\
\hline Checklist matrix & $\begin{array}{l}\text { Way of analyzing/displaying one major concept, variable, or } \\
\text { domain that includes several unordered components }\end{array}$ \\
\hline \multicolumn{2}{|l|}{ Time-Ordered } \\
\hline Event listing & $\begin{array}{l}\text { Matrix or flowchart that organizes a series of concrete events by } \\
\text { chronological time periods and sorts them into multiple } \\
\text { categories }\end{array}$ \\
\hline Critical incident chart & Maps a few critical events \\
\hline Event-state network & Maps general states that are not as time-limited as events, and \\
\hline
\end{tabular}




\begin{tabular}{|c|c|}
\hline & $\begin{array}{l}\text { might represent moderators or mediators that link specific events } \\
\text { of interest }\end{array}$ \\
\hline Activity record & $\begin{array}{l}\text { Displays a specific recurring activity that is limited narrowly in } \\
\text { time and space }\end{array}$ \\
\hline Decision modeling flowchart & $\begin{array}{l}\text { Maps thoughts, plans, and decisions made during a flow of } \\
\text { activity that is bounded by specific conditions }\end{array}$ \\
\hline Growth gradient & $\begin{array}{l}\text { Network that maps events that are conceptualized as being } \\
\text { linked to an underlying variable that changes over time }\end{array}$ \\
\hline Time-ordered matrix & Maps when particular phenomena occurred \\
\hline \multicolumn{2}{|l|}{ Role-Ordered } \\
\hline Role-ordered matrix & $\begin{array}{l}\text { Maps the participant's "roles" by sorting data in rows and } \\
\text { columns that have been collected from or about a set of data that } \\
\text { reflect their views, beliefs, expectations, and/or behaviors }\end{array}$ \\
\hline Role-by-time matrix & Maps the participant's "roles," preserving chronological order \\
\hline \multicolumn{2}{|l|}{ Conceptually Ordered } \\
\hline Conceptually clustered matrix & $\begin{array}{l}\text { Text table with rows and columns arranged to cluster items that } \\
\text { are related theoretically, thematically, or empirically }\end{array}$ \\
\hline Thematic conceptual matrix & Reflects ordering of themes \\
\hline Folk taxonomy & $\begin{array}{l}\text { Typically representing a hierarchical tree diagram that displays } \\
\text { how a person classifies important phenomena }\end{array}$ \\
\hline Cognitive map & $\begin{array}{l}\text { Displays the person's representation of concepts pertaining to a } \\
\text { particular domain }\end{array}$ \\
\hline Effects matrix & $\begin{array}{l}\text { Displays data yielding one or more outcomes in a differentiated } \\
\text { manner, focusing on the outcome/dependent variable }\end{array}$ \\
\hline Case dynamics matrix & $\begin{array}{l}\text { Displays a set of elements for change and traces the } \\
\text { consequential processes and outcomes for the purpose of initial } \\
\text { explanation }\end{array}$ \\
\hline Causal network & $\begin{array}{l}\text { Displays the most important independent and dependent } \\
\text { variables and their inter-relationships }\end{array}$ \\
\hline
\end{tabular}

\subsubsection{Cross-Case Displays}

Miles and Huberman (1994) also constructed an array (i.e., $n=18$ ) of visual displays for multiple cases (i.e., cross-case displays). Cross-case displays comprise partially ordered displays, case-ordered displays, time-ordered displays, and conceptually ordered displays. Specifically, partially ordered displays comprise partially ordered meta-matrices, which represent Level 3 visual display (cf. Table 2). Case-ordered displays range from Level 3 (e.g., case-ordered descriptive meta-matrix; cf. Table 2) to Level 5 (e.g., scatterplot; cf. Table 2). 
Time-ordered displays also range from Level 3 (e.g., include time-ordered meta-matrix; cf. Table 2) to Level 5 (e.g., causal models; cf. Table 2). Finally, conceptually ordered displays similarly range from Level 3 (e.g., content-analytic summary table; cf. Table 2) to Level 5 (e.g., decision tree modeling; cf. Table 2). As noted by Miles and Huberman (1994),

Such visual displays can be designed to assemble organized information into an immediately accessible, compact form so that the analyst can see what is happening and either draw justified conclusions or move on to the next step of analysis the display suggests may be useful. (p. 11)

Table 2. Miles and Huberman's (1994) cross-case displays

\begin{tabular}{|c|c|}
\hline Type of Display & Description \\
\hline \multicolumn{2}{|l|}{ Partially Ordered } \\
\hline Partially ordered meta-matrices & $\begin{array}{l}\text { Display descriptive data for each of several cases } \\
\text { simultaneously }\end{array}$ \\
\hline \multicolumn{2}{|l|}{ Case-Ordered } \\
\hline $\begin{array}{l}\text { Case-ordered descriptive } \\
\text { meta-matrix }\end{array}$ & $\begin{array}{l}\text { Contains descriptive data from all cases but the cases are } \\
\text { ordered by the main variable of interest }\end{array}$ \\
\hline $\begin{array}{l}\text { Two-variable case-ordered } \\
\text { matrix }\end{array}$ & $\begin{array}{l}\text { Displays descriptive data from all cases but the cases are } \\
\text { ordered by two main variables of interest that are represented by } \\
\text { the rows and columns }\end{array}$ \\
\hline Contrast table & $\begin{array}{l}\text { Displays a few exemplary cases wherein the variable occurs in } \\
\text { low or high form, and contrast several attributes of the basic } \\
\text { variable }\end{array}$ \\
\hline Scatterplot & $\begin{array}{l}\text { Plot all cases on two or more axes to determine how close from } \\
\text { each other the cases are }\end{array}$ \\
\hline Case-ordered effects matrix & $\begin{array}{l}\text { Sorts cases by degrees of the major cause of interest, and shows } \\
\text { the diverse effects for each case }\end{array}$ \\
\hline $\begin{array}{l}\text { Case-ordered predictor-outcome } \\
\text { matrix }\end{array}$ & $\begin{array}{l}\text { Arranges cases with respect to a main outcome variable, and } \\
\text { provides data for each case on the main antecedent variables }\end{array}$ \\
\hline $\begin{array}{l}\text { Predictor-outcome } \\
\text { consequences matrix }\end{array}$ & $\begin{array}{l}\text { Links a chain of predictors to some intermediate outcome, and } \\
\text { then illustrates the consequence of that outcome }\end{array}$ \\
\hline \multicolumn{2}{|l|}{ Time-Ordered } \\
\hline Time-ordered meta-matrix & $\begin{array}{l}\text { Table in which columns are organized sequentially by time } \\
\text { period and the rows are not necessarily ordered }\end{array}$ \\
\hline Time-ordered scatterplot & Display similar variables in cases over two or more time periods \\
\hline Composite sequence analysis & Permit extraction of typical stories that several cases share, \\
\hline
\end{tabular}




\begin{tabular}{|c|c|}
\hline & without eliminating meaningful sequences \\
\hline \multicolumn{2}{|l|}{ Conceptually Ordered } \\
\hline Content-analytic summary table & $\begin{array}{l}\text { Allows the researcher to focus on the content of a meta-matrix } \\
\text { without reference to the underlying case }\end{array}$ \\
\hline Substructing & Permits the identification of underlying dimensions \\
\hline Decision tree modeling & $\begin{array}{l}\text { Displays decisions and actions that are made across several } \\
\text { cases }\end{array}$ \\
\hline Variable-by-variable matrix & $\begin{array}{l}\text { Table that displays two major variables in its rows and columns } \\
\text { ordered by intensity with the cell entries representing the cases }\end{array}$ \\
\hline Causal models & $\begin{array}{l}\text { Network of variables with causal connections among them in } \\
\text { order to provide a testable set of propositions or hunches about } \\
\text { the complete network of variables and their interrelationships }\end{array}$ \\
\hline Causal networks & $\begin{array}{l}\text { Comparative analysis of all cases using variables deemed to be } \\
\text { the most influential in explaining the outcome or criterion }\end{array}$ \\
\hline Antecedents matrix & $\begin{array}{l}\text { Display that is ordered by the outcome variable, and displays all } \\
\text { of the variables that appear to change the outcome variable }\end{array}$ \\
\hline
\end{tabular}

Moreover, in addition to augmenting data display, visual displays in general and graphics in particular can enhance data reduction and conclusion drawing/verification (Miles \& Huberman, 1994). With regard to data reduction, graphics, in particular, provide a way of organizing, simplifying, focusing, summarizing, documenting, sorting, transforming, and discarding text (Miles \& Huberman, 1994). With regard to conclusion drawing/verification, visual displays not only can help researchers make inferences and conclusions, but also they can help them to assess continually the trustworthiness, credibility, dependability, confirmability, and/or transferability of the inferences made. Consequently, visual displays serve as an important part of any analysis process because the decisions made as to which visual display(s) to select represent analytical processes (Onwuegbuzie \& Dickinson, 2008). Further, as noted by Onwuegbuzie and Dickinson (2008), visual displays "can serve as a thread that interweaves data reduction, data display, and conclusion drawing/verification in the tapestry (i.e., report) that emerges" (p. 207). Thus, it is surprising that visual displays are under-utilized in literature review reports. Table 1 and Table 2 present a summary of each of Miles and Huberman's (1994) within-case and cross-case displays.

\section{Mapping Miles and Huberman's Within-Case and Cross-Case Analysis Methods onto the Literature Review Process}

We believe that all 19 within-case analyses and 18 cross-case analyses conceptualized by Miles and Huberman (1994) can be mapped onto the literature review process. Indeed, in our own work, we have used several of each of Miles and Huberman's (1994) within-case displays and cross-case displays to analyze and to display information extracted for literature reviews. Table 3 and Table 4 present a summary of how each of Miles and Huberman's (1994) 
within-case and cross-case displays can be applied to analyzing and interpreting information that inform literature reviews.

Table 3. Miles and Huberman's (1994) within-case displays mapped onto the literature review process

\begin{tabular}{|c|c|}
\hline Type of Display & Description \\
\hline \multicolumn{2}{|l|}{ Partially Ordered } \\
\hline Poem & $\begin{array}{l}\text { Analyzing information using poetry; also known as interpretive } \\
\text { poem, found poetry (e.g., Prendergast, 2006), research experience } \\
\text { poem, poem from the field, or data poem (cf. Lahman et al., } \\
\text { 2010) }\end{array}$ \\
\hline Context chart & $\begin{array}{l}\text { Using networks that map in graphic form the interrelationships } \\
\text { among groups studied by researchers and roles that underlie the } \\
\text { context of individual behavior }\end{array}$ \\
\hline Checklist matrix & $\begin{array}{l}\text { Analyzing/displaying one major concept, variable, or domain that } \\
\text { includes several unordered components }\end{array}$ \\
\hline \multicolumn{2}{|l|}{ Time-Ordered } \\
\hline Event listing & $\begin{array}{l}\text { Using a matrix or flowchart to organize a series of concrete events } \\
\text { by chronological time periods and to sort them into multiple } \\
\text { categories }\end{array}$ \\
\hline Critical incident chart & Mapping a few critical events across the literature \\
\hline Event-state network & $\begin{array}{l}\text { Mapping general states that are not as time-limited as events, and } \\
\text { that might represent moderators or mediators that link specific } \\
\text { events of interest }\end{array}$ \\
\hline Activity record & $\begin{array}{l}\text { Displaying a specific recurring activity across the literature that is } \\
\text { limited narrowly in time and space }\end{array}$ \\
\hline Decision modeling flowchart & $\begin{array}{l}\text { Mapping thoughts, plans, and decisions made during a flow of } \\
\text { activity that is bounded by specific conditions }\end{array}$ \\
\hline Growth gradient & $\begin{array}{l}\text { Using a network to map events that are conceptualized as being } \\
\text { linked to an underlying variable that changes over time }\end{array}$ \\
\hline Time-ordered matrix & Mapping when particular phenomena occurred \\
\hline \multicolumn{2}{|l|}{ Role-Ordered } \\
\hline Role-ordered matrix & $\begin{array}{l}\text { Mapping the "roles" of each selected work by sorting data in rows } \\
\text { and columns that have been collected from or about a set of data } \\
\text { that reflect the views, beliefs, expectations, and/or behaviors of } \\
\text { the authors/researchers }\end{array}$ \\
\hline
\end{tabular}




\begin{tabular}{|c|c|}
\hline Role-by-time matrix & $\begin{array}{l}\text { Mapping the "roles" of each selected work and preserving } \\
\text { chronological order }\end{array}$ \\
\hline \multicolumn{2}{|l|}{ Conceptually Ordered } \\
\hline Conceptually clustered matrix & $\begin{array}{l}\text { Creating a text table with rows and columns arranged to cluster } \\
\text { items that are related theoretically, thematically, or empirically }\end{array}$ \\
\hline Thematic conceptual matrix & Using a display that reflects the ordering of themes \\
\hline Folk taxonomy & $\begin{array}{l}\text { Typically representing a hierarchical tree diagram that displays } \\
\text { how a researcher/author classifies important phenomena }\end{array}$ \\
\hline Cognitive map & $\begin{array}{l}\text { Displaying the researcher's/author's representation of concepts } \\
\text { pertaining to a particular domain }\end{array}$ \\
\hline Effects matrix & $\begin{array}{l}\text { Displaying data yielding one or more outcomes in a differentiated } \\
\text { manner, focusing on the outcome/dependent variable of interest }\end{array}$ \\
\hline Case dynamics matrix & $\begin{array}{l}\text { Displaying a set of elements for change and tracing the } \\
\text { consequential processes and outcomes for the purpose of initial } \\
\text { explanation }\end{array}$ \\
\hline Causal network & $\begin{array}{l}\text { Displaying the most important independent and dependent } \\
\text { variables across the information sources and their } \\
\text { inter-relationships }\end{array}$ \\
\hline
\end{tabular}

Table 4. Miles and Huberman's (1994) cross-case displays mapped onto the literature review process

\begin{tabular}{|c|c|}
\hline Type of Display & Description \\
\hline \multicolumn{2}{|l|}{ Partially Ordered } \\
\hline Partially ordered meta-matrices & $\begin{array}{l}\text { Displaying descriptive data for each of the selected information } \\
\text { sources simultaneously }\end{array}$ \\
\hline \multicolumn{2}{|l|}{ Case-Ordered } \\
\hline $\begin{array}{l}\text { Case-ordered descriptive } \\
\text { meta-matrix }\end{array}$ & $\begin{array}{l}\text { Including descriptive data from all information sources but the } \\
\text { information sources are ordered by the main variable of interest }\end{array}$ \\
\hline Two-variable case-ordered matrix & $\begin{array}{l}\text { Displaying descriptive data from all information sources but the } \\
\text { information sources are ordered by two main variables of } \\
\text { interest that are represented by the rows and columns }\end{array}$ \\
\hline Contrast table & $\begin{array}{l}\text { Displaying a few exemplary information sources wherein the } \\
\text { variable occurs in low or high form, and contrast several } \\
\text { attributes of the basic variable }\end{array}$ \\
\hline Scatterplot & $\begin{array}{l}\text { Plotting all information sources on two or more axes to } \\
\text { determine how close from each other the information sources }\end{array}$ \\
\hline
\end{tabular}




\begin{tabular}{|c|c|}
\hline & are \\
\hline Case-ordered effects matrix & $\begin{array}{l}\text { Sorting information sources by degrees of the major cause of } \\
\text { interest, and showing the diverse effects for each information } \\
\text { source }\end{array}$ \\
\hline $\begin{array}{l}\text { Case-ordered predictor-outcome } \\
\text { matrix }\end{array}$ & $\begin{array}{l}\text { Arranging information sources with respect to a main outcome } \\
\text { variable, and providing data for each information source on the } \\
\text { main antecedent variables }\end{array}$ \\
\hline $\begin{array}{l}\text { Predictor-outcome consequences } \\
\text { matrix }\end{array}$ & $\begin{array}{l}\text { Linking a chain of predictors to some intermediate outcome, } \\
\text { and then illustrating the consequence of that outcome }\end{array}$ \\
\hline \multicolumn{2}{|l|}{ Time-Ordered } \\
\hline Time-ordered meta-matrix & $\begin{array}{l}\text { Creating a table in which columns are organized sequentially by } \\
\text { time period and the rows are not necessarily ordered }\end{array}$ \\
\hline Time-ordered scatterplot & $\begin{array}{l}\text { Displaying similar variables across information sources over } \\
\text { two or more time periods }\end{array}$ \\
\hline Composite sequence analysis & $\begin{array}{l}\text { Allowing extraction of typical stories that several information } \\
\text { sources share, without eliminating meaningful sequences }\end{array}$ \\
\hline \multicolumn{2}{|l|}{ Conceptually Ordered } \\
\hline Content-analytic summary table & $\begin{array}{l}\text { Allowing the reviewer to focus on the content of a meta-matrix } \\
\text { without reference to the underlying information source }\end{array}$ \\
\hline Substructing & Allowing the identification of underlying dimensions \\
\hline Decision tree modeling & $\begin{array}{l}\text { Displaying decisions and actions that are made across several } \\
\text { information sources }\end{array}$ \\
\hline Variable-by-variable matrix & $\begin{array}{l}\text { Creating a table that displays two major variables in its rows } \\
\text { and columns ordered by intensity with the cell entries } \\
\text { representing the information sources }\end{array}$ \\
\hline Causal models & $\begin{array}{l}\text { Creating a network of variables with causal connections among } \\
\text { them in order to provide a testable set of propositions or } \\
\text { hunches about the complete network of variables and their } \\
\text { interrelationships }\end{array}$ \\
\hline Causal networks & $\begin{array}{l}\text { Conducting a comparative analysis of all information sources } \\
\text { using variables deemed to be the most influential in explaining } \\
\text { the outcome or criterion }\end{array}$ \\
\hline Antecedents matrix & $\begin{array}{l}\text { Creating a display that is ordered by the outcome variable, and } \\
\text { displaying all of the variables that appear to change the outcome } \\
\text { variable }\end{array}$ \\
\hline
\end{tabular}




\section{Heuristic Example}

\subsection{Stage 1}

The purpose of Frels's (2010) qualitative investigation (i.e., a multiple case study; Stake 2005) was to explore selected mentors' perceptions and experiences of the dyadic mentoring relationship in school-based mentoring - a type of helping relationship that is facilitated by a mentor-optimally serving as the facilitator of change to impact the mentee as well as the mentor. In addition, she sought to understand roles, purposes, approaches, and experiences of the relationship process with mentees (i.e., the dyadic relationship).

As recommended by Onwuegbuzie and Frels (2016), Frels (2010) conducted a comprehensive literature review on the topic of mentoring that involved multiple search phases using a culturally progressive, ethical, and multimodal approach. In being culturally progressive, we mean that Frels (2010) operated under the assumption that "knowledge sources stem from people (i.e., participants) and are generated by people (i.e., researchers, authors) who represent all cultures, races, ethnic backgrounds, languages, classes, religions, and other diversity attributes" (Onwuegbuzie \& Frels, 2016, p. xiii). In assuming an ethical stance, Frels (2010) adopted "best practices in not only research but also the subject discipline of the topic explored" (Onwuegbuzie \& Frels, 2016, p. 38) and attempted to maximize integrity, scholarly responsibility, social responsibility, and respecting rights, dignity, and diversity. Finally, she undertook a multimodal approach via the examination of multimodal texts and settings that comprised five MODES (i.e., Media, Observation(s), Documents, Expert(s) in the field, and Secondary sources; Onwuegbuzie \& Frels, 2016).

Specifically, Frels's (2010) multiple phases comprised five search phases pertaining to the mentoring literature that was retrieved via bibliographic searches and a sixth search phase that involved extending her search via the aforementioned five MODES, which included communicating with authors who had published in the field of research and mentoring. Her six search phases led to the identification of 47 relevant articles using the following criteria: (a) the research or concept illuminated or extended her understanding (i.e., provided meaning) of the phenomenon of mentoring in general and mentoring relationships in particular; and (b) the research design was rigorous and was characterized by displaying "vividness, creativity, thoroughness, congruence, and sensitivity" (Frels, 2010, p. 40). Figure 2 presents a visual representation (i.e., a flowchart) of the number of articles identified at each phase of her information search process. 


\section{Macrothink}

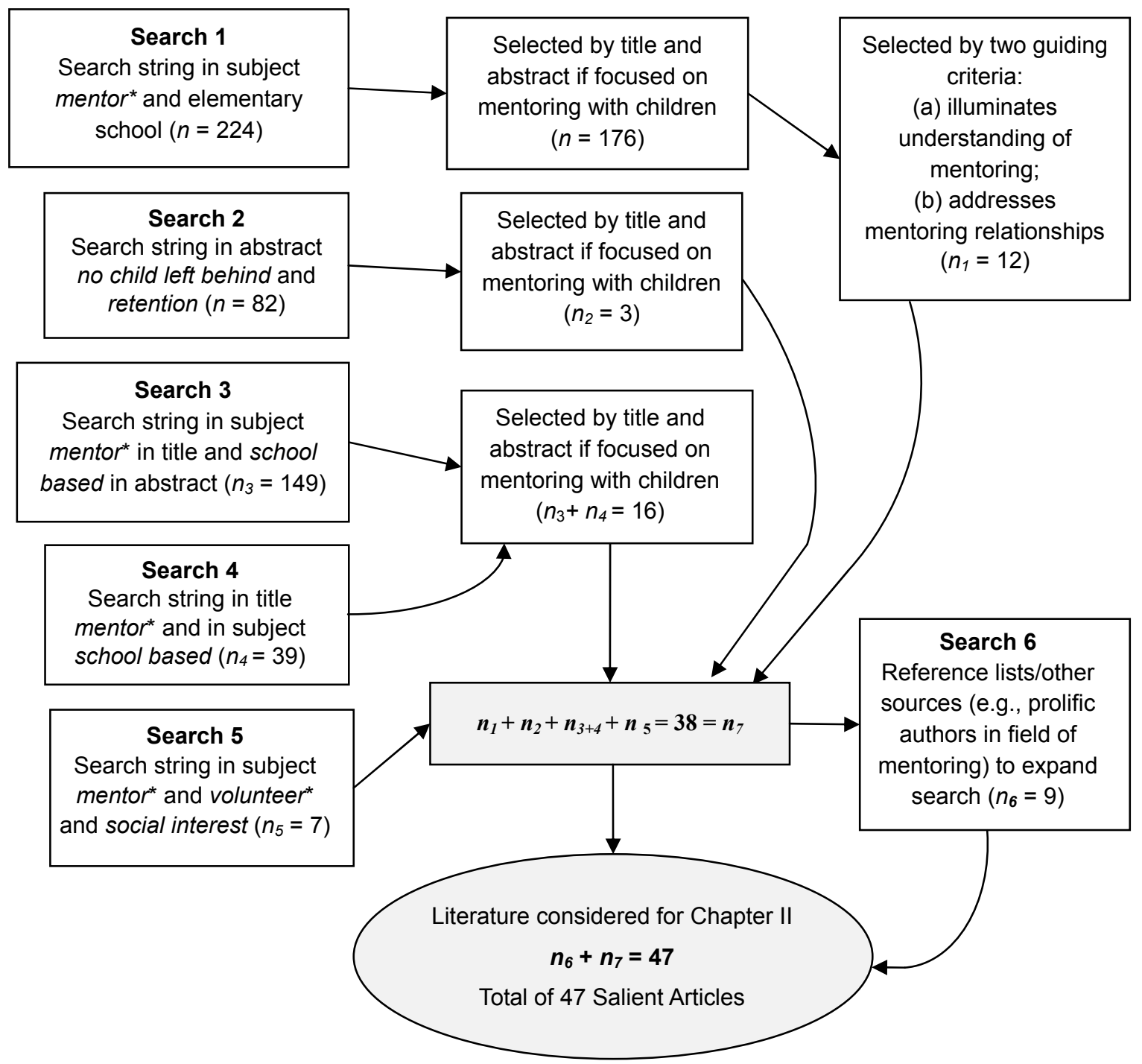

Figure 2. The six search phases of Frels' (2010) literature review chapter with respect to the field of school-based literature

\subsection{Stage 2}

After identifying set of relevant sources (i.e., Stage 1), the next phase involved Frels (2010) storing and organizing this set of 47 sources. As noted by Onwuegbuzie and Frels (2016), sources selected during the literature review process can be stored and organized in an array of ways that vary as a function of level of complexity - specifically, via basic tools (e.g., index cards, word processing software programs [e.g. Microsoft Word]), intermediate tools (e.g., spreadsheets [e.g., Microsoft Excel]; web-based applications (e.g., Google Drive; Dropbox); Internet-based social bookmarking services (e.g., ResearchGate [http://www.researchgate. net/]), or advanced strategies (e.g., reference management software programs [e.g., EndNote; Mendeley]; computer-assisted qualitative data analysis software [CAQDAS; e.g., QDA Miner 4.1; Provalis Research, 2015]). However, we recommend that literature reviews store and organize information electronically. Indeed, optimally, we 
recommend that the reviewer imports the sources (e.g., articles) using a CAQDAS program. Of these CAQDAS programs, we particularly recommend the use of QDA Miner (Provalis Research, 2015) because of its ability to facilitate the following analysis via the following displays: (a) descriptive analysis (i.e., barcharts and pie charts); (b) comparison analysis (i.e., correspondence analysis, heatmap with dual clustering); and (c) co-occurrence of codes and similarity of documents (i.e., hierarchical cluster analysis, multidimensional scaling).

\subsection{Stage 3}

The literature reviewer's next task is to decide whether to conduct one or more within-case analyses and/or one or more cross-case analyses. A within-case analysis is undertaken by reading each of Frels's (2010) 47 mentoring-based articles as many times as is needed and deciding on which of the 19 types of within-case displays best enhance meaning. In contrast, a cross-case analysis involves comparing and contrasting Frels's (2010) 47 mentoring-based articles and determining which of the 18 types of cross-case displays are most pertinent. Here, each literature source represents a case; thus, in the current example, there were 47 cases.

Based on the 47 works that she had extracted from the six phases of her search, Frels (2010) created a causal model that displayed the complete network of variables and their interrelationships. Specifically, Frels (2010) used Deutsch and Spencer's (2009) concept of the dyadic setting - representing the intimate exchange between mentor and mentee as a setting within itself - to create a figure (cf. Figure 3) that illustrated the mentor and the dyadic relationship, incorporating Bronfenbrenner's (1979) ecological theory and Mullen's (1999) synergetic comentoring framework. Bronfenbrenner's (1979) ecological systems model comprises four levels, or layers, of environment that impact a child's or adolescent's development: (a) the microsystem (Level 1): the immediate environment with which the child/adolescent closely interacts (e.g., home, classroom, playground, recreation center, religious institution); (b) the mesosystem (Level 2): the other systems in which the child/adolescent spends time (e.g., family and school); (c) the exosystem (Level 3): the systems by which the child/adolescent might be influenced but of which he/she is not directly a member (e.g., the relationships among school teachers, the school administrators, the child's/adolescent's parents or other close family members); and (d) the macrosystem (Level 4): the larger cultural world surrounding the child/adolescent such as the society (e.g., state, region, country) or community at large that includes societal belief systems, cultural norms, ideologies, policies, or laws that indirectly influence the child/adolescent. Through synergetic comentoring framework, Mullen (1999) conceptualized mentoring "as a form of coengagement, reeducation, productivity, and innovation” (Frels, 2010, p. 9). Frels (2010) described this figure as follows:

The environment of culture, belief system, and experiences of mentors impact the dyadic exchange. Mentors might integrate initial and on-going trainings to influence their roles and approaches to the dyadic relationship. Furthermore, [this] [f]igure ... illustrates that both direct and indirect inputs from mentoring program administration influence both the mentor and the dyadic relationship for either successful outcomes or discouragement and ultimate termination of mentoring. (p. 102) 


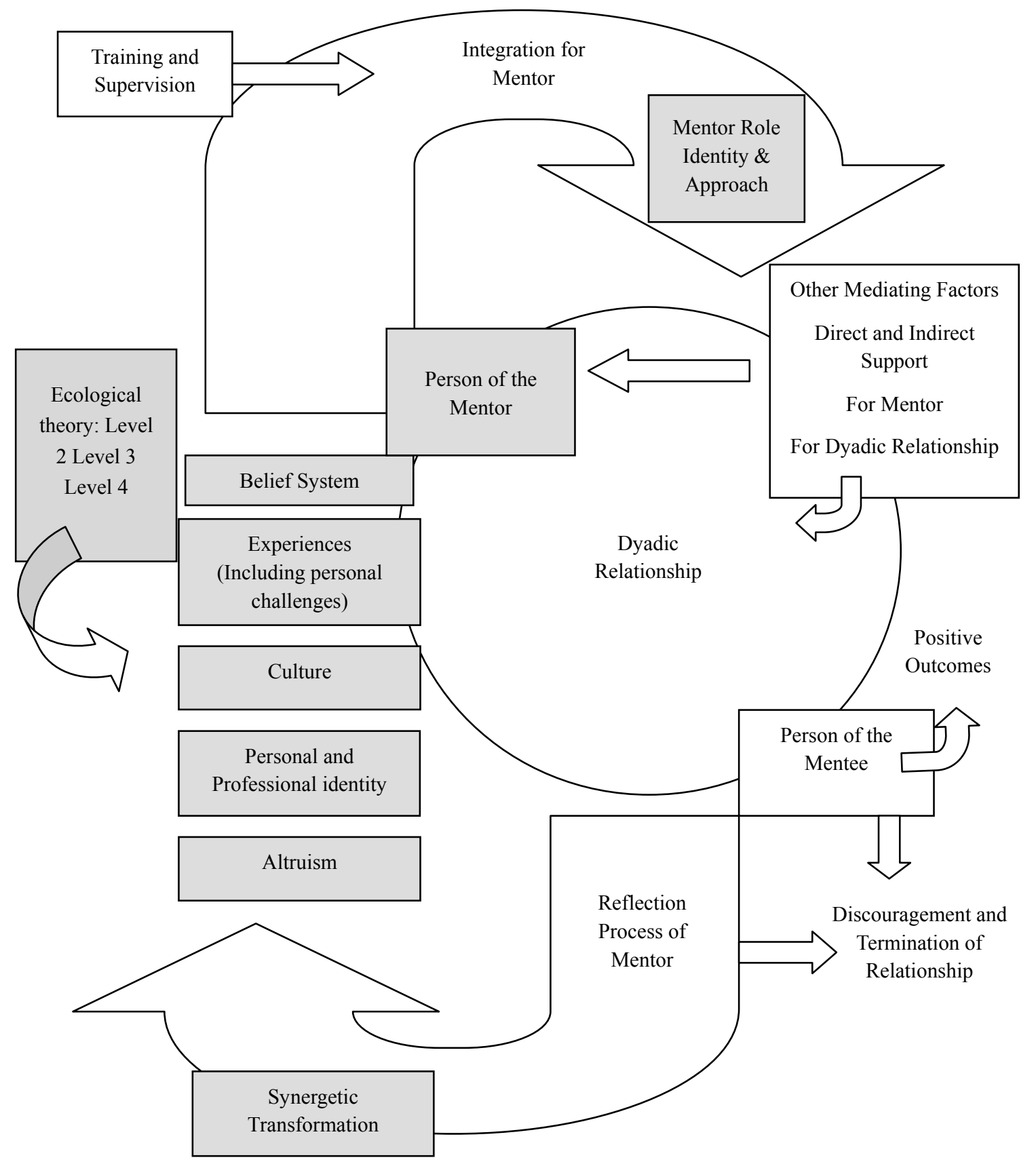

Figure 3. Frels's (2010) depiction of the mentor and the influences of Bronfenbrenner's (1979) ecological theory and Mullen's (1999) synergetic co-mentoring in the dyadic relationship

Note. Adapted from "The experiences and perceptions of selected mentors: An exploratory study of the dyadic relationship in school-based mentoring" by R. K. Frels, 2010, Unpublished doctoral dissertation, Sam Houston State University, Huntsville, TX, p. 103. Copyright 2010 by R. K. Frels.

Figure 3 represents a Level 5 display - the highest level of display. However, a lower level display — even a Level 1 display — also can provide a powerful representation of the data. For 
example, poetry - a Level 1 display — can be used as an avenue for a researcher to access universality (Furman, Langer, Davis, Gallardo, \& Kulkami, 2007), with the literature review poet using information extracted from a literature review to create a product that is universal or generalizable because the readers can identify with the ensuing synthesis (Onwuegbuzie \& Frels, 2016). Onwuegbuzie and Frels (2016) concluded that research poetry provides an avenue for a researcher to access universality, with poets using their personal experiences to create a product that is universal or generalizable because the readers identify with the work. As an example, Onwuegbuzie (2012) used what Onwuegbuzie and Frels (2016) refer to as a synthesis poem after he conducted a comprehensive literature review regarding arguments between researchers who conduct purely quantitative research and researchers who conduct purely qualitative research — which was referred to by Gage (1989) as the paradigm war-which has occurred between purists representing both traditions since the 1980s. Interestingly, Onwuegbuzie's (2012) synthesis poem represented a cross-case display (i.e., representing a synthesis across all the works) rather than a within-case display (as conceptualized in Table 3). Figure 4 presents the first seven verses of Onwuegbuzie's (2012) synthesis poem. 
Generation Q: A Dream for Mixed Researchers in the Radical Middle

QUAN researchers on one side;

QUAL researchers on the other;

Anyone in-between;

Ends up being smothered.

A discipline built on division, turmoil and tears.

Much blood has been spilt

throughout the years.

QUAN and QUAL researchers

claim the other paradigm is flawed;

But when it comes to methodological tolerance

good practices are ignored.

QUAN and QUAL researchers

often have been segregated

And for those wanting unity,

this has been ill-fated.

Scholars from other fields

are extremely surprised;

for many can see through

this paradigmatic disguise.

All educational researchers

I think you will find,

compared to other disciplines

are many years behind.

Mixed research in some journals

has been virtually forbidden;

to publish in these journals,

mixed research identities must be hidden.

Figure 4. First seven verses of a synthesis poem written by Onwuegbuzie (2012) that provided a synthesis of the debates that have occurred between purists representing the quantitative and qualitative research traditions since the $1980 \mathrm{~s}$

Note. Adapted from "Introduction: Putting the mixed back into quantitative and qualitative research in educational research and beyond: Moving towards the radical middle," by A. J. Onwuegbuzie, 2012, International Journal of Multiple Research Approaches, 6, p. 212. Copyright 2012 by eContent Management Pty Ltd. 


\section{Macrothink}

Finally, although most of the time, Miles and Huberman's (1994) visual displays can be used as an end goal - namely, to provide a visual representation of the analysis and synthesis of the information extracted from the literature review-these displays also can be used to inform subsequent qualitative, quantitative, or mixed analyses. As an illustration, DuBois, Holloway, Valentine, and Cooper (2002), who conducted a meta-analytic review of 55 articles (i.e., 55 cases) regarding the effectiveness of mentoring programs for youth, developed an index of the characteristics of the 11 best practices for mentoring programs. Onwuegbuzie and Frels (2015) used these data to construct a case-ordered effects matrix (i.e., sorting cases by degrees of the major cause of interest, and showing the diverse effects for each case; see Table 4) involving the following three characteristics of best practices: mentoring relationship monitoring, mentor training, and structured activities. Within this matrix, Onwuegbuzie and Frels (2015) documented which mentoring programs representing these 55 articles were effective or not in retaining mentors and/or mentees - which served as the outcome variable. Next, they dichotomized the outcome variable depending on whether the program was effective (i.e., coded as "1") or not (i.e., coded as "0"). Similarly, the three input variables (i.e., mentoring relationship monitoring, mentor training, and structured activities) were dichotomized according to whether the element was present (i.e., coded as "1") or absent (i.e., coded as " 0 ") within the program. This dichotomization yielded what Ragin (1987) referred to as a truth table, which summarized the pattern of outcomes (i.e., whether or not the mentoring program was effective) associated with different configurations of causal conditions (i.e., characteristics of best practices). As conceptualized by Ragin (1987), a truth table presents the different combinations of causal conditions and the value of the outcome variable for the cases (i.e., articles) conforming to each combination. This truth table, which contains $0 \mathrm{~s}$ and $1 \mathrm{~s}$, is presented in Table 5 . This truth table then was subjected to a qualitative comparative analysis (Ragin, 1987) to determine which of these three characteristics was a necessary and/or sufficient cause of mentoring program effectiveness. In particular, this qualitative comparative analysis of the truth table in Table 5 suggested the importance of mentoring relationship monitoring in securing an effective mentoring program (Onwuegbuzie \& Frels, 2015). 
Table 5. Truth table for selected characteristics of best practices for mentoring programs among 55 selected articles stemming from a Miles and Huberman (1994) case-ordered effects matrix

\begin{tabular}{|l|l|l|l|}
\hline \multicolumn{3}{|c|}{ Conditions } & \multicolumn{1}{c|}{ Outcome } \\
\hline $\begin{array}{l}\text { Mentoring Relationship } \\
\text { Monitoring (MRM) }\end{array}$ & $\begin{array}{l}\text { Mentor Training } \\
(\mathrm{MT})\end{array}$ & $\begin{array}{l}\text { Structured } \\
\text { Activities (SA) }\end{array}$ & $\begin{array}{l}\text { Mentoring Program } \\
\text { Effective (MPE)? }\end{array}$ \\
\hline 0 & 0 & 0 & 0 \\
\hline 0 & 0 & 1 & 0 \\
\hline 0 & 1 & 0 & 1 \\
\hline 0 & 1 & 1 & 3 \\
\hline 1 & 0 & 0 & 10 \\
\hline 1 & 0 & 1 & 9 \\
\hline 1 & 1 & 0 & 12 \\
\hline 1 & 1 & 1 & 20 \\
\hline & & Total & 55 \\
\hline
\end{tabular}

\section{Conclusion}

In this article, we contended that there is scant guidance on how to analyze sources that inform a literature review. Even more disturbingly, there is minimal guidance as to how to use visual displays to enhance literature review reports. At the time of writing, Miles and Huberman's (1994) textbook has been cited in more than 58,000 works, which makes it by far the most cited qualitative data analysis textbook and the second most cited qualitative research book (after Glaser and Strauss's [1967] book with more than 77,000 citations). Therefore, it is surprising that, to date, Miles and Huberman's (1994) textbook has not been used as a framework for analyzing and interpreting sources that stem from literature reviews. Subsequently, this has been our goal in the current article. Specifically, we have illustrated how literature reviewers can undertake a 3-step process for creating visual displays to analyze and to synthesize information extracted from literature reviews via Miles and Huberman's (1994) within- and cross-case displays. We believe that the use of visual displays has incremental validity for helping beginning and seasoned reviewers alike map the qualitative data analysis process onto the literature review process, thereby potentially yielding a more multidimensional, interactive, emergent, iterative, systematic, dynamic, holistic, and synergistic process of exploring, interpreting, synthesizing, and communicating information that is extracted from a comprehensive literature review.

\section{References}

Boote, D. N., \& Beile, P. (2005). Scholars before researchers: On the centrality of the dissertation literature review in research preparation. Educational Researcher, 34(6), 3-15. 
http://dx.doi.org/10.3102/0013189X034006003

Bronfenbrenner, U. (1979). The ecology of human development: Experiments by nature and design. Cambridge, MA: Harvard University Press.

Combs, J. P., Bustamante, R. M., \& Onwuegbuzie, A. J. (2010). A mixed methods approach to conducting literature reviews for stress and coping researchers: An interactive literature review process framework. In G. S. Gates, W. H. Gmelch, \& M. Wolverton (Series Eds.); K. M. T. Collins, A. J. Onwuegbuzie, \& Q. G. Jiao (Eds.), Toward a broader understanding of stress and coping: Mixed methods approaches (pp. 213-241). The Research on Stress and Coping in Education Series (Vol. 5). Charlotte, NC: Information Age Publishing.

Dellinger, A., \& Leech, N. L. (2007). A validity framework: A unified approach to evaluating validity of empirical research. Journal of Mixed Methods Research, 1, 309-332. http://dx.doi.org/10.1177/1558689807306147

Deutsch, N. L., \& Spencer, R. (2009). Capturing the magic: Assessing the quality of youth mentoring relationships. New Directions for Youth Development, 121, 47-70. http://dx.doi.org/10.1002/yd.296

Dickinson, W. B., Hines, C. V., \& Onwuegbuzie, A. J. (March, 2006). Graphical analysis of clandestine methamphetamine laboratories utilizing PROC GMAP: A visual inventory of activity across the United States. Proceedings of the Thirty-first SAS Users Group International Conference (Paper 136-31). Cary, NC: SAS Institute. Retrieved, from http://www2.sas.com/proceedings/sugi31/136-31.pdf

Dubois, D. L., Holloway, B. E., Valentine, J. C., \& Cooper, H. (2002). Effectiveness of mentoring programs for youth: A meta-analytic review. American Journal of Community Psychology, 30, 157-197. http://dx.doi.org/10.1023/A:1014628810714

Fink, A. (2009). Conducting research literature reviews: From the Internet to paper. Thousand Oaks, CA: Sage.

Frels, R. K. (2010). The experiences and perceptions of selected mentors: An exploratory study of the dyadic relationship in school-based mentoring (Unpublished doctoral dissertation, Sam Houston State University, Huntsville, TX, USA).

Furman, R., Langer, C. L., Davis, C. S., Gallardo, H. P., \& Kulkami, S. (2007). Expressive research and reflective poetry as qualitative inquiry: A study of adolescent identity. Qualitative Research, 7, 301-315. http://dx.doi.org/10.1177/1468794107078511

Gage, N. L. (1989). The paradigm wars and their aftermath: A "historical" sketch of research on teaching since 1989. Educational Researcher, 18, 4-10. http://dx.doi.org/10.3102/0013189X018007004

Garrard, J. (2009). Health sciences literature review made easy: The matrix method. Sudbury, MA: Jones and Bartlett.

Geertz, C. (1973). Thick description toward an interpretive theory of culture. In C. Geertz 
(Ed.), The interpretation of cultures (pp. 3-30). New York, NY: Basic Books.

Glaser, B. G., \& Strauss, A. L. (1967). The discovery of grounded theory: Strategies for qualitative research. Chicago, IL: Aldine.

Hart, C. (2005). Doing a literature review: Releasing the social science research imagination. London, England: Sage.

Lahman, M. K. E., Geist, M. R., Rodriguez, K. L., Graglia, P. E., Richard, V. M., \& Schendel, R. K. (2010). Poking around poetically: Research, poetry, and trustworthiness. Qualitative Inquiry, 16, 39-8. doi:10.1177/1077800409350061

Leech, N. L., Dellinger, A., Brannagan, K. B., \& Tanaka, H. (2010). Evaluating mixed research studies: A mixed methods approach. Journal of Mixed Methods Research, 4, 17-31. http://dx.doi.org/10.1177/1558689809345262

Machi, L. A., \& McEvoy, B. T. (2009). The literature review: Six steps to success. Thousand Oaks, CA: Corwin Press.

Miles, M., \& Huberman, A. M. (1994). Qualitative data analysis: An expanded sourcebook (2nd ed.). Thousand Oaks, CA: Sage.

Mullen, C. A. (1999). Introducing new directions for mentoring. In C. A. Mullen \& D. W. Lick (Eds.), New directions in mentoring: Creating a culture of synergy (pp. 10-17). New York, NY: Routledge.

Onwuegbuzie, A. J. (2012). Introduction: Putting the mixed back into quantitative and qualitative research in educational research and beyond: Moving towards the radical middle. International Journal of Multiple Research Approaches, 6, 192-219. http://dx.doi.org/10.5172/mra.2012.6.3.192

Onwuegbuzie, A. J., Collins, K. M. T., Leech, N. L., Dellinger, A. B., \& Jiao, Q. G. (2010). A meta-framework for conducting mixed research syntheses for stress and coping researchers and beyond. In G. S. Gates, W. H. Gmelch, \& M. Wolverton (Series Eds.); K. M. T. Collins, A. J. Onwuegbuzie, \& Q. G. Jiao (Eds.), Toward a broader understanding of stress and coping: Mixed methods approaches (pp. 169-211). The Research on Stress and Coping in Education Series (Vol. 5). Charlotte, NC: Information Age Publishing.

Onwuegbuzie, A. J., \& Combs, J. P. (2010). Emergent data analysis techniques in mixed methods research: A synthesis. In A. Tashakkori \& C. Teddlie (Eds.), Sage Handbook of mixed methods in social and behavioral research (2nd ed., pp. 397-430). Thousand Oaks, CA: Sage.

Onwuegbuzie, A. J., \& Daniel, L. G. (2005). Editorial: Evidence-based guidelines for publishing articles in Research in the Schools and beyond. Research in the Schools, 12(2), $1-11$.

Onwuegbuzie, A. J., \& Dickinson, W. B. (2008). Mixed methods analysis and information visualization: Graphical display for effective communication of research results. The 
Qualitative Report, 13, 204-225. Retrieved from http://www.nova.edu/ssss/QR/QR13-2/ Onwuegbuzie.pdf

Onwuegbuzie, A. J., \& Frels, R. K. (2012). Writing a literature review. In C. Wagner, B. Kawulich, \& M. Garner (Eds.). Doing social research: A global context (pp. 29-51). Maidenhead, England: McGraw-Hill.

Onwuegbuzie, A. J., \& Frels, R. K. (2014). A framework for using discourse analysis for the review of the literature in counseling research. Counseling Outcome Research and Evaluation, 5, 52-63. http://dx.doi.org/10.1177/2150137813515905

Onwuegbuzie, A. J., \& Frels, R.K. (2015, April). A framework for using qualitative comparative analysis for the review of the literature. Paper presented at the annual meeting of the American Educational Research Association, Chicago, IL.

Onwuegbuzie, A. J., \& Frels, R. K. (2016). Seven steps to a comprehensive literature review: A multimodal and cultural approach. London, England: Sage.

Onwuegbuzie, A. J., \& Leech, N. L. (2005). A typology of errors and myths perpetuated in educational research textbooks. Current Issues in Education [On-line], 8(7). Retrieved from http://cie.ed.asu/volume8/number7

Onwuegbuzie, A. J., Leech, N. L., \& Collins, K. M. T. (2011). Innovative qualitative data collection techniques for conducting literature reviews. In M. Williams \& W. P. Vogt (Eds.), The Sage handbook of innovation in social research methods (pp. 182-204). Thousand Oaks, CA: Sage.

Onwuegbuzie, A. J., Leech, N. L., \& Collins, K. M. T. (2012). Qualitative analysis techniques for the review of the literature. The Qualitative Report, 17(Art. 56), 1-28. Retrieved from http://www.nova.edu/ssss/QR/QR17/onwuegbuzie.pdf

Prendergast, M. (2006). Found poetry as literature review: Research poems on audience and performance. Qualitative Inquiry, 12, 369-88. http://dx.doi.org/10.1177/1077800405284601

Provalis Research. (2015). QDA Miner (Version 4.1) [Computer software]. Montreal, Quebec, Canada: Author.

Ragin, C. C. (1987). The comparative method: Moving beyond qualitative and quantitative strategies. Berkeley, CA: University of California Press.

Ridley, D. (2008). The literature review: A step-by-step guide for students. Thousand Oaks, CA: Sage.

Stake, R. E. (2005). Qualitative case studies. In N. K. Denzin \& Y. S. Lincoln (Eds.), The Sage handbook of qualitative research (3rd ed., pp. 443-466). Thousand Oaks, CA: Sage.

Tufte, E. R. (2001). The visual display of quantitative information (2nd ed.). Cheshire, CT: Graphics Press.

Tufte, E. R. (2006). Beautiful evidence. Cheshire, CT: Graphics Press. 


\section{Copyright Disclaimer}

Copyright for this article is retained by the author(s), with first publication rights granted to the journal.

This is an open-access article distributed under the terms and conditions of the Creative Commons Attribution license (http://creativecommons.org/licenses/by/3.0/). 